\title{
PERAN KOMUNIKASI DALAM PENDIDIKAN
}

\section{Arif Khoiruddin*}

\begin{abstract}
Abstrak:
Komunikasi merupakan sarana penting bagi tenaga pengajar dalam menyelenggarakan kegiatan belajar dan pembelajaran dimana akan membangun pemahaman peserta didiknya tentang materi yang diajarkan. Melalui komunikasi sebagai sumber menyampaikan informasi adalah materi pembelajaran kepada penerima yaitu peserta didik dengan menggunakan simbol-simbol baik lisan, tulisan, dan bahasa non-verbal. Sebaliknya peseta didik akan menyampaikan berbagai pesan sebagai respon kepada tenaga pengajar tersebut sehingga terjadi komunikasi dua arah guna meningkatkan keberhasilan komunikasi untuk mencapai tujuan pembelajaran yaitu terjadinya perubahan tingkah laku dalam diri siswa. Out put pendidikan juga akan lebih bermakna jika terjalin komunikasi yang intensif antara guru dan siswa. Sebab dengan komunikasi yang intensif, guru dapat mengetahui kondisi Psikologis peserta didik dan tingkat perkembangan emosional siswa. Selain itu, guru juga mengetahui secara akurat tingkat kesulitan yang dialami siswa dalam proses pembelajaran.
\end{abstract}

Kata Kunci: komunikasi, pendidikan

\section{Pendahuluan}

Komunikasi merupakan bagian dari kehidupan manusia sehari-hari, karena tanpa komunikasi tidak akan mungkin terjadi proses interaksi sosial, baik secara individu maupun kelompok. Sebagai makhluk sosial manusia dituntut untuk saling berinteraksi, saling melakukan aksi dan reaksi baik secara verbal (kata-kata lisan dan atau tulisan) maupun secara non-verbal (isyarat, sikap, tingkah laku). 
Dalam Islam sendiri identifikasi ayat al-Qur'an tentang komunikasi verbal di antaranya perkataan yang baik (Q.S. $2: 235 ; 4: 5,8$; dan 33:32), perkataan yang tegas (Q.S. 4:9 dan 33:70), perkataan yang berbekas (Q.S. 4:63), perkataan yang mulia (Q.S. 17:23), perkataan yang santun (Q.S. 17:28), perkataan yang luhur (Q.S. 17:40), perkataan yang lembut (Q.S. 20:44), perkataan yang berat (Q.S. 73:5), perkataan yang lebih baik (Q.S. 17:53), dan perkataan yang terbaik (Q.S. 41:33). ${ }^{1}$

Allah berfirman:

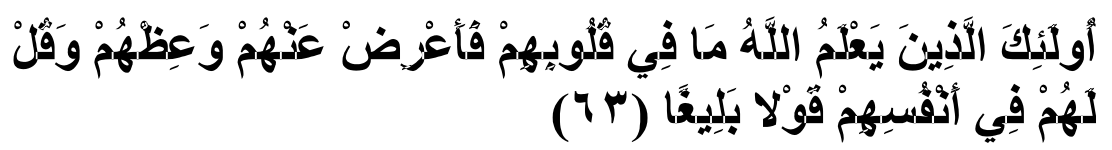

Terjemahnya: Mereka itu adalah orang-orang yang Allah mengetahui apa yang di dalam hati mereka. karena itu berpalinglah kamu dari mereka, dan berilah mereka pelajaran, dan Katakanlah kepada mereka Perkataan yang berbekas pada jiwa mereka. ${ }^{2}$

Islam sebagai Dien (Agama) yang sempurna tentu akan dapat disosialisasikan dan diinternalisasikan kepada para pemeluknya untuk lebih dihayati dan diamalkan secara murni dan konsekuen, jika disampaikan oleh guru agama atau muballigh yang mampu melakukan komunikasi verbal secara efektif. Kalau saja para guru agama Islam menguasai metode berkomunikasi verbal dengan efektif, akan dapat menginternalisasikan ajaran Islam dalam benak dan dada semua murid sehingga dapat besikap dan berperilaku sebagai muslim sejati.

Dalam pendidikan komunikasi merupakan sarana bagi guru dalam menyelenggarakan proses belajar dan pembelajaran dimana guru akan membangun pemahaman siswa tentang materi yang diajarkan. Melalui komunikasi guru sebagai sumber

* Institut Agama Islam Tribakti (IAIT) Kediri

1 Muhammad Djarot Sensa, Komunikasi Quraniyah, (Bandung: Pustaka Islamika, 2005), h. 107

2 Departemen Agama RI Al-Quran tajwid dan terjemahnya (Bandung: PT Syaamil Cipta Madia, 2006), h. 88 
menyampaikan informasi dalam hal ini materi pembelajaran kepada penerima yaitu siswa dengan menggunakan simbolsimbol baik lisan, tulisan, dan bahasa non-verbal. Sebaliknya siswa akan menyampaikan berbagai pesan sebagai respon kepada guru sehingga terjadi komunikasi dua arah guna meningkatkan keberhasilan komunikasi untuk mencapai tujuan pembelajaran yaitu terjadinya perubahan tingkah laku dalam diri siswa.

Guru merupakan orang yang dianggap mampu mentransfer materi ajar, gagasan, wawasan lainnya kepada siswa haruslah dipandang sebagai sebuah proses belajar mengajar. Tetapi guru juga tidak boleh anti kritik, justru dengan kritik dan saran itu akan menambah wawasan lain dan umpan balik dalam belajar akan semakin hidup dan menyenangkan. Jangan sampai guru memiliki sifat otoriter atas semua kebijakan di sekolah saat mengajar, jangan jadikan siswa sebagai objek. Justru sebaliknya, siswa harus dijadikan subjek dalam sebuah pembelajaran.

Di sinilah pentingnya seorang guru memiliki komunikasi yang lancar, baik dan mampu menggerakkan siswa untuk melakukan interaksi. Membuat suasana belajar menyenangkan, nyaman, dan tak tertekan. Guru bukan hanya sebagai orang yang mengajar, tetapi lebih dari itu yakni sebagai orang tua, rekan, maupun sahabat. Karena ada siswa yang tidak mau terbuka kepada orang tua, tetapi kepada guru bisa terbuka terkait dengan persoalan atau masalah yang sedang dihadapinya, sehingga rasa kasih sayang dari seorang guru kepada siswa akan menjadikan motivasi tersendiri. Kemudian guru yang berperan sebagai teman harus mampu membuat siswa bergaul dengan leluasa dalam artian ada batasnya. Jelas ini akan menambah percaya diri siswa dalam belajar. Karena pada hakikatnya tujuan komunikasi itu adalah bagaimana bisa dan mampu merubah suatu sikap (attitude), pendapat (opinion), perilaku (behavior), ataupun perubahan secara sosial (social change).

\section{Pengertian Komunikasi}

Vol. 23 Nomor. 1 Januari 2012 
Secara etimologis, "komunikasi" berasal dari kata latin "communicatio" yang diturunkan dari kata Communis yang berarti membuat kebersamaan atau membangun kebersamaaan antara dua orang atau lebih. Akar dari kata Communis adalah Communico yang artinya berbagi. Dalam hal ini, yang berbagi adalah pemahaman bersama melalui pertukaran pesan. ${ }^{3}$

Definisi komunikasi oleh kelompok sarjana komunikasi yang mengkhususkan diri pada studi komunikasi antar manusia (human communication) bahwa: "Komunikasi adalah suatu transaksi, proses simbolik yang menghendaki orang-orang mengatur lingkungannya dengan (1) membangun hubungan antar sesama manusia; (2) melalui pertukaran informasi; (3) untuk menguatkan sikap dan tingkah laku orang lain; serta (4) berusaha mengubah sikap dan tingkah laku itu". ${ }^{4}$

Menurut Hovland dalam bukunya Hafied Cangara Proses komunikasinya sendiri diartikan: "Suatu proses dimana seseorang menyampaikan lambang-lambang dalam bentuk katakata, dengan maksud untuk mengubah tingkah laku orang lain."5 Menurut Supratiknya mengungkapkan bahwa komunikasi sebagai setiap bentuk tingkah laku seseorang baik verbal maupun nonverbal yang ditanggapi oleh orang lain ${ }^{6}$ Sedangkan menurut Kartono komunikasi adalah arus informasi dan emosi yang terdapat dalam masyarakat, baik yang berlangsung secara vertikal maupun horisontal. $^{7}$

Ada beberapa faktor yang dapat mempengaruhi kelancaran seseorang dalam berkomunikasi yaitu:

1. Faktor pengetahuan, makin luas pengetahuan yang dimiliki seseorang, semakin banyak pembendaharaan kata yang

${ }^{3}$ Dani Vardiansyah, Filsafat Ilmu Komunikasi, (Jakarta: PT Indeks, 2008), h. 24

${ }^{4}$ Hovland (1953: 188) dalam H. Hafied Cangara, Pengantar Ilmu Komunikasi, (Jakarta: PT Raja Grafindo Persada, 2008), h. 19-20

5 Darwanto, Televisi Sebagai Media Pendidikan, (Yogyakarta: Pustaka Pelajar, 2007), h. 15

Konisius, 1995), h.20

6 Supratiknya, komunikasi Antar Pribadi, (Yogyakarta:

${ }_{7}$ Kartono, Psikologi Sosial untuk Manajemen Perusahaan dan Industri, (Jakarta: Raja Grafindo Persada, 2002), h.212

Vol. 23 Nomor. 1 Januari 2012 
dimiliki sehingga mempermudah berkomunikasi dengan lancar.

2. Faktor pengalaman, makin banyak pengalaman yang dimiliki seseorang menyebabkan terbiasa untuk menghadapi sesuatu.

3. Faktor inteligensi, orang yang inteligensinya rendah biasanya kurang lancar dalam berbicara karena kurang memiliki pembendaharaan kata dan bahasa yang baik

4. Faktor kepribadian, orang yang mempunyai sifat pemalu dan kurang bergaul, biasanya kurang lancar berbicara dibandingkan dengan orang yang pandai bergaul.

5. Faktor biologis, antara lain disebabkan karena gangguan orang-orang berbicara sehingga menimbulkan gangguan dalam berkomunikasi. ${ }^{8}$

Komunikasi antar manusia hanya bisa terjadi, jika ada seseorang yang menyampaikan pesan kepada orang lain tujuan tertentu, artinya komunikasi hanya bisa terjadi kalau didukung oleh adanya sumber, pesan, media, penerima, dan efek. Unsurunsur ini bisa juga disebut komponen atau elemen komunikasi.

Adapun unsur-unsur dalam komunikasi yaitu:

1. Komunikator, seseorang atau beberapa orang yang menyampaikan informasi (pesan) kepada komunikan.

2. Komunikan, seseorang atau beberapa orang yang menerima informasi dari komunikator.

3. Informasi, sesuatu yang ingin disampaikan kepada komunikan. Informasi ini terbagi lagi menjadi dua yaitu informasi yang dikirimkan dan informasi yang diterima. Selain dua hal ini, ketika komunikator menyampaikan info kepada komunikan pasti memiliki tujuan informasi yaitu tujuan ketika informasi tersebut disampaikan

4. Media, sarana yang digunakan untuk menyalurkan informasi dari komunikator kepada komunikan

5. Umpan balik atau efek, tanggapan (respon) atau reaksi dari komunikan ketika menerima informasi dari komunikator ${ }^{9}$

8 Bambang warsita, Teknologi Pembelajaran (Landasan dan aplikasinya), (Jakarta: Rineka Cipta, 2008), h. 99

${ }^{9}$ Mohyi, Ahmad, 1999, Teori dan Perilaku Organisasi, (Malang: UMM Press, 1999) h. 112-113 


\section{Bentuk Dasar Komunikasi}

Komunikasi yang efektif tentu saja memiliki beberapa alat untuk menyampaikan suatu pesan. Mereka tahu bagaimana menempatkan kata yang membentuk arti, bagaimana mengajak peserta untuk aktif diskusi dan apakah pesan tersebut akan disampaikan secara tulisan atau lisan.mereka juga memperkuat kata-kata mereka dengan gerak isyarat dan tindakan.

Dalam komunikasi ada dua macam bentuk yaitu komunikasi lisan/ komunikasi verbal dan komunikasi non lisan/ non verbal.

\section{Komunikasi Lisan atau Komunikasi Verbal}

Komunikasi verbal adalah bentuk komunikasi yang dilakukan dengan menggunakan simbol-simbol atau kata-kata baik lisan maupun tulisan. Komunikasi ini hanya dapat dilakukan oleh manusia. Dengan memanipulasi kata-kata manusia dapat mengkomunikasikan berbagai pesan yang rumit sekalipun seperti Undang-Undang, perhitungan matematika, sastra, dan ilmu pengetahuan lainnya. Oleh sebab itu, guru harus menguasai dengan baik cara melakukan komunikasi verbal agar tidak menjadi hambatan semantik di antaranya ketika berkomunikasi dengan siswa dalam belajar dan pembelajaran.

Dalam komunikasi lisan, informasi disampaikan secara lisan atau verbal melalui apa yang diucapkan dari mulut atau dikatakan, dan bagaimana mengatakannya. Arti kata yang diucapkan akan lebih jelas apabila ucapan yang diikuti dengan tekanan suara melalui tinggi rendahnya dan lemah lembutnya suara, keras tidaknya suara, dan perubahan nada suara ${ }^{11}$. Informasi yang disampaikan secara lisan, melalui ucapan katakata atau kalimat disebut dengan berbicara. Berbicara merupakan salah satu usaha untuk mengungkapkan perasaan, gagasan, dan ide dengan ucapan, kata-kata atau tulisan yang menggunakan bentuk tertentu.

Seseorang yang piawai dalam melakukan komunikasi verbal lazim disebut dengan komunikator efektif. Berdasar teori yang ada, seorang komunikator baru disebut efektif jika

${ }^{10}$ Nitisesmito, Alex, 1989, Manajemen personalia, (Kudus: Mandar Maju, 1989), h.252

${ }^{11}$ Bambang warsita, Teknologi Pembelajaran, h. 100 
memiliki indikator: Credibility, Capability, Clarity, Symphaty dan Enthusiasity

a) Credibility (citra diri)

Hal ini berkaitan dengan prestasi, spesifikasi keilmuan, kompetensi, pengalaman dalam bidang yang ditekuni, nama baik, jasa-jasa dalam bidang tertentu, temuan, popularitas, serta dedikasinya terhadap profesi yang ditekuni.

b) Capability

Seorang pembicara efektif dituntut memiliki kecakapan atau kemampuan memadai. Tidak harus pintar sekali memang, tetapi memadai cukup dalam beberapa hal di antaranya: 1). Kecakapan mengemukakan pikiran secara singkat, jelas, tetapi padat. 2). Kecakapan mempertahankan pikiran atau pendapat, dalam forum pertemuan yang bersifat dialogis atau komunikasi dua arah seperti dalam diskusi atau seminar. 3). Kemampuan mengkoordinasikan dan mengkombinasikan secara tepat komuniksi verbal dan non verbal

c). Clarity

Dapat dideskripsikan sebagai kejelasan dan ketepatan ucapan. Penerapan komunikasi verbal banyak bertumpu pada clarity. Sampai atau tidaknya penyampaian pesan dari seorang pembicara, banyak ditentukan oleh keterampilan penguasaan teknik vokalnya. Keterampilan tersebut sangat dipengaruhi tingkat kejelasan penyampaian materi atau pesan

d). Sympathy

Penampilan simpatik seorang Pembicara merupakan buah dari perpaduan serasi antara ketulusan, kesabaran dan kegembiraan Pembicara yang mampu tampil simpatik sepanjang ceramahnya akan merasa puas dan memuaskan audience. Materi pembicaraan disampaikan dengan cara simpatik, sehingga diikuti dengan penuh antusias dan akhirnya dapat dipahami dengan jelas. Sementara pembicara mendapatkan kepuasan bathiniah, karena melihat wajahwajah yang penuh antusiasme dan puas dengan apa yang didapatkan darinya. Indikator penampilan simpatik seorang pembicara dapat dideteksi melalui intensitas senyum, kontak mata, keramahan sikap, keterbukaan penampilan, serta 
keceriaan wajah. Bagi pembicara yang memiliki open face, tidak terlalu sulit baginya untuk bersikap simpatik. Tetapi seorang pembicara yang termasuk kategori neutral face memerlukan usaha, dan bagi pemilik Close Face dituntut kerja keras dalam berlatih.

5). Enthusiasity,

Orang Indonesia menyebut istilah di atas dengan antusiasme Audience cenderung lebih menyenangi pembicara yang tampil antusias, yang tercermin dari semangat tinggi, gerak lincah, penampilan energik, stamina yang fit, wajah berseriseri. Untuk dapat tampil antusias atau gairah tinggi, seorang pembicara harus memiliki fisik sehat serta hati yang gembira. Sulit rasanya membayangkan seorang pembicara yang sedang tidak enak badan atau sakit, dapat tampil prima penuh antusiasme. Dalam keadaan sehat, pembicara memiliki peluang tampil antusias, karena tampak fit, fresh, segar, tegar, bugar, lincah, bergerak, penuh aksi, ringan tubuh, dan luwes. Semua ini dapat memancing antusiasme audience untuk mengikuti ceramah, Meskipun menyenangi pembicara yang antusias dan lincah, namun demikian audience tidak menyenangi sikap yang berlebihan, terlebih jika sikap tersebut mengarah kepada kesan kenes, genit, sombong dan over acting. ${ }^{12}$

Ada pun Komunikasi verbal mempunyai karakteristik: (1) Jelas dan ringkas; (2) Pembendaharaan kata mudah difahami; (3) Mempunyai arti kata denotatif dan konotatif; (4) Intonasi mampu mempengaruhi isi pesan; (5) Kecepatan bicara yang memiliki tempo dan jeda yang tepat; dan (6) Disertai unsur humor.

\section{Komunikasi non-lisan/komunikasi non-verbal}

Blake dan Haroldsen dengan singkat mengemukakan bahwa Komunikasi non-verbal adalah penyampaian dari pesan yang meliputi ketidak hadiran simbol-simbol atau perwujudan suara. Termasuk dalam komunikasi non-verbal adalah kontak

12 Imam Mudjiono, Konsep Komunikasi dalam Al-Quran. http://imamu.staff.uii.ac.id, diakses 19 september 2011) 
mata, ekspresi wajah, gerak tubuh, kedekatan jarak, suara yang bukan kata atau pribahasa, sentuhan, dan cara berpakaian. ${ }^{13}$

Ada empat hal yang perlu difahami berkenaan bahasa non-verbal yang dapat dimanfaatkan oleh guru dalam menyelenggarakan belajar dan pembelajaran yaitu:

a. Komunikasi non-verbal terikat dengan kebudayaan jadi bukan sifat instink manusiawi dan berbeda satu budaya ke budaya yang lainnya

b. Isyarat non-verbal mengungkapkan makna: para ahli mengatakan bahwa porsi non-verbal memberikan 70-90 arti yang ditarik orang dari pesannya

c. Ketika pesan-pesan non-verbal bertentangan dengan pesan verbal, kebanyakan orang mempercayai pesan non-verbal

d. Tidak ada bahasa yang lengkap dan sempurna di dunia. Oleh karena itu untuk melengkapi keterbatasan tersebut gunakanlah bahasa non-verbal ${ }^{14}$

Mark L. Knapp menyebut lima fungsi pesan nonverbal yang dihubungkan dengan pesan verbal:

a. Repetisi, yaitu mengulang kembali gagasan yang sudah disajikan secara verbal. Misalnya setelah mengatakan penolakan saya, saya menggelengkan kepala.

b. Substitusi, yaitu menggantikan lambang-lambang verbal. Misalnya tanpa sepatah katapun kita berkata, kita menunjukkan persetujuan dengan mengangguk-anggukkan kepala.

c. Kontradiksi, menolak pesan verbal atau memberi makna yang lain terhadap pesan verbal. Misalnya anda "memuji" prestasi teman dengan mencibirkan bibir, seraya berkata "Hebat, kau memang hebat."

d. Komplemen, yaitu melengkapi dan memperkaya makna pesan nonverbal. Misalnya, air muka anda menunjukkan tingkat penderitaan yang tidak terungkap dengan kata-kata.

e. Aksentuasi, yaitu menegaskan pesan verbal atau menggarisbawahinya. Misalnya, anda mengungkapkan betapa jengkelnya anda dengan memukul meja. ${ }^{15}$

13 Abdorrakhman Gintings, Belajar dan Pembelajaran, (Bandung: Humaniora, 2008), h. 126

${ }^{14}$ Abdorrakhman Gintings, Belajar dan.., h. 126 
Yang termasuk komunikasi non verbal:

a). Ekspresi wajah

Wajah merupakan sumber yang kaya dengan komunikasi, karena ekspresi wajah cerminan suasana emosi seseorang

b). Kontak mata,

Merupakan sinyal alamiah untuk berkomunikasi. Dengan mengadakan kontak mata selama berinterakasi atau tanya jawab berarti orang tersebut terlibat dan menghargai lawan bicaranya dengan kemauan untuk memperhatikan bukan sekedar mendengarkan. Melalui kontak mata juga memberikan kesempatan pada orang lain untuk mengobservasi yang lainnya.

c) Sentuhan

Adalah bentuk komunikasi personal mengingat sentuhan lebih bersifat spontan dari pada komunikasi verbal. Beberapa pesan seperti perhatian yang sungguh-sungguh, dukungan emosional, kasih sayang atau simpati dapat dilakukan melalui sentuhan.

d) Postur tubuh dan gaya berjalan.

Cara seseorang berjalan, duduk, berdiri dan bergerak memperlihatkan ekspresi dirinya. Postur tubuh dan gaya berjalan merefleksikan emosi, konsep diri, dan tingkat kesehatannya.

e) Sound (Suara).

Rintihan, menarik nafas panjang, tangisan juga salah satu ungkapan perasaan dan pikiran seseorang yang dapat dijadikan komunikasi. Bila dikombinasikan dengan semua bentuk komunikasi non verbal lainnya sampai desis atau suara dapat menjadi pesan yang sangat jelas

f). Gerak isyarat

Adalah yang dapat mempertegas pembicaraan, menggunakan isyarat sebagai bagian total dari komunikasi seperti mengetuk-ngetukan kaki atau mengerakkan tangan selama berbicara menunjukkan seseorang dalam keadaan stress bingung atau sebagai upaya untuk menghilangkan stress.

15 Adi Prakosa, Komunikasi Verbal Dan Non-Verbal. (http://adiprakosa.blogspot.com di akses 19 September 2011)

Vol. 23 Nomor. 1 Januari 2012 


\section{Kemampuan Guru dalam Berkomunikasi}

Agardapat berkomunikasi dengan baik, guru perlu memiliki kemampuan berbahasa yang baik. Ia perlu memiliki kekayaan bahasa dan kosa kata yang cukup banyak sebab dengan menggunakan kata-kata tertentu saja siswa belum dapat memahami maknanya, mereka membutuhkan kata-kata atau istilah lain. Guru perlu menguasai struktur kalimat dan ejaan yang benar. Struktur kalimat dan ejaan yang salah dari guru, akan ditiru salah pula, dan dapat membingungkan. Hal yang juga cukup penting dalam berbahasa ini, guru perlu menguasai ucapan dan ragam bahasa yang tepat dan baik. Setiap orang memiliki pembawaan suara dan logat sendiri. Meski pun demikian guru yang memiliki logat yang berbeda-beda ini harus berusaha untuk menggunakan logat bahasa Indonesia yang benar.

Hal lain yang juga sangat penting dalam berkomunikasi dengan bahasa ini bagi guru adalah tinggi rendahnya nada suara dan keras lemahnya bicara. Setiap orang juga memiliki volume suara yang berbeda, ada yang tinggi halus, tinggi kasar, rendah halus, rendah kasar, dan sebagainya. Kebiasaan berbicara pun berbeda-beda ada yang cepat atau lambat, keras atau pelan. Sebagai guru hendaknya berusaha memiliki volume suara yang sedang dengan kecepatan dan nada yang sedang pula, sebab sebagaian besar anak-anak memiliki kondisi seperti itu.

Selain kemampuan berbahasa hal yang juga penting dalam interaksi pendidikan dan pengajaran adalah penampilan guru. Setiap orang karena pembawaannya juga memiliki ciri-ciri fisik tertentu, berkulit sawo matang atau hitam, bertubuh besar atau kecil, berkulit kasar atau halus, bermuka lonjong atau persegi. Meski pun demikian guru atau calon guru hendaknya mengusahakan penampilan yang moderat, dengan memperlihatkan sikap bersahabat, keramahan, keterbukaan, penghargaan akan martabat siswa, kesediaan untuk membantu dan lain-lain. Penampilan kepribadian tidak semata-mata ditentukan oleh aspek fisik, tetapi keharmonisan antara aspek fisik dengan psikis.

Kemampuan berkomunikasi guru dalam kelas juga dipengaruhi oleh penguasaan guru akan bahan yang akan diajarkan. Guru yang tidak menguasai bahan, tidak akan lancar 
dalam menyampaikan pelajaran, banyak berhenti atau melihat buku, bahkan mungkin banyak berbuat kekeliruan. Kekakuan dan kekeliruan yang diperlihatkan guru akan menyebabkan kegelisahan pada siswa, yang akhirnya dapat mengakibatkan kurangnya perhatian, kurangnya penghargaan baik pada pelajaran maupun pada guru. ${ }^{16}$

\section{Peran Komunikasi Bagi Pendidikan}

Untuk meningkatkan keberhasilan pelaksanaan tugasnya dalam penyelenggaraan belajar dan pembelajaran, selain kompetensi lainnya (kompetensi pedagogik, kompetensi kepribadian, dan kompetensi profesional), guru harus memiliki kompetensi sosial (komunikasi), karena komunikasi merupakan sarana utama dalam belajar dan pembelajaran.

Komunikasi merupakan sarana penting bagi guru dalam menyelenggarakan proses belajar dan pembelajaran dimana guru akan membangun pemahaman siswa tentang materi yang diajarkan. ${ }^{17}$ Melalui komunikasi guru sebagai sumber menyampaikan informasi, adalah materi pembelajaran, kepada penerima yaitu siswa dengan menggunakan simbol-simbol baik lisan, tulisan, dan bahasa non-verbal. Sebaliknya siswa akan menyampaikan berbagai pesan sebagai respon kepada guru sehingga terjadi komunikasi dua arah guna meningkatkan keberhasilan komunikasi untuk mencapai tujuan pembelajaran yaitu terjadinya perubahan tingkah laku dalam diri siswa.

Dalam Unsur-unsur komunikasi ada umpan balik/feedback yaitu informasi yang kembali dari komunikasi (siswa) ke komunikator (guru) sebagai respon terhadap pesan yang disampaikan oleh komunikator (guru). Dalam konteks pendidikan, umpan balik ini sangat penting artinya bagi keberhasilan belajar dan pembelajaran. dengan adanya umpan balik dari siswa, guru akan mengetahui apakah materi yang disampaikan telah difahami dan apa kesulitan siswa dalam memahami jika ada selanjutnya tindakan remedial apa yang perlu dilakukannya.

16 Nana Syaodih Sukmadinata, Landasan Psikologi Proses Pendidikan, (Bandung: PT Remaja Rosdakarya, 2005), h. 259-260

${ }^{17}$ Abdorrakhman Gintings, Belajar dan..., h. 117 
Sebaliknya, umpan balik dari guru misalnya dalam bentuk nilai atas hasil kerja siswa akan mengingatkan kepada siswa sampai sejauh mana penguasaannya terhadap materi yang sedang dipelajari. Berdasarkan umpan balik tersebut siswa dapat memutuskan tindakan apa yang harus dilakukan untuk meningkatkan hasil belajarnya jika kurang memuaskan. ${ }^{18}$

\section{Kesimpulan}

Komunikasi merupakan sarana penting bagi guru dalam menyelenggarakan proses belajar dan pembelajaran dimana guru akan membangun pemahaman siswa tentang materi yang diajarkan. Output pendidikan akan lebih bermakna jika terjalin komunikasi yang intensif antara guru dan siswa. Sebab dengan komunikasi yang intensif, guru dapat mengetahui kondisi Psikologis peserta didik dan tingkat perkembangan emosional siswa. Selain itu, guru juga mengetahui secara akurat tingkat kesulitan yang dialami siswa dalam proses pembelajaran.

${ }^{18}$ Abdorrakhman Gintings, Belajar dan, h 121 


\section{DAFTAR PUSTAKA}

Muhammad Djarot Sensa, Komunikasi Quraniyah, Bandung: Pustaka Islamika, 2005)

Departemen Agama RI Al-Quran tajwid dan terjemahnya, Bandung: PT Syaamil Cipta Madia, 2006

Dani Vardiansyah, Filsafat Ilmu Komunikasi, Jakarta: PT Indeks, 2008

Hovland (1953: 188) dalam H. Hafied Cangara, Pengantar Ilmu Komunikasi, Jakarta: PT Raja Grafindo Persada, 2008

Darwanto, Televisi Sebagai Media Pendidikan, Yogyakarta: Pustaka Pelajar, 2007

Supratiknya, komunikasi Antar Pribadi, Yogyakarta: Konisius, 1995

Kartono, Psikologi Sosial untuk Manajemen Perusahaan dan Industri, Jakarta: Raja Grafindo Persada, 2002

Bambang warsita, Teknologi Pembelajaran Landasan dan aplikasinya), Jakarta: Rineka Cipta, 2008

Mohyi, Ahmad, 1999, Teori dan Perilaku Organisasi, Malang: UMM Press, 1999

Nitisesmito, Alex, 1989, Manajemen personalia, Kudus: Mandar Maju, 1989

Imam Mudjiono, Konsep Komunikasi dalam Al-Quran. http://imamu.staff.uii.ac.id

Abdorrakhman Gintings, Belajar dan Pembelajaran, Bandung: Humaniora, 2008

Adi Prakosa, Komunikasi Verbal Dan Non-Verbal. http://adiprakosa.blogspot.com

Nana Syaodih Sukmadinata, Landasan Psikologi Proses Pendidikan, Bandung: PT Remaja Rosdakarya, 2005), h. 259-260 